\title{
Global Citizenship Education for (Unknown) Futures of Education
}

\author{
Reflections on skills-and competency-based versus virtue-based \\ education
}

KAREN BJERG PETERSEN

\begin{abstract}
A 'World in 2030' survey carried out by UNESCO in the months May through September 2020 indicates that "climate change and biodiversity loss" by far are the biggest concerns of the around 15.000 participants, who at the same time indicate that education and multilateralism are seen as the most important solutions to global issues. In this article, I will discuss possibilities and limitations of (global citizenship) education in versions of skills-and competency-based versus virtue/value-based approaches as means of solving current global issues and concerns, including (unknown) futures of education at a local and global level.
\end{abstract}

KEYWORDS: Global citizenship education; UNESCO; OECD; virtue-based education; skillsand competency-based education

A survey entitled " world in 2030" carried out in 2020 by UNESCO Clearing House on Global Citizenship Education (2020) indicates that "climate change and loss of biodiversity" are two of the five biggest challenges anticipated by the around 15.000 participants in the public survey. The survey participants emphasise that apart from multilateralism, education is considered one of the most important ways of solving global issues. The result of the survey is described as follows:

In fact, education was consistently highlighted as a solution, from teaching about critical thinking, respect, online ethics and media literacy, to promoting health, civics, heritage and gender equality. This reflects a collective conviction in the importance of education not only as an end in and of itself, but as a valid and wide-reaching solution to our many and varied global challenges (UNESCO Clearing House 2020 (bold from original quote)).

The emphasis on education as being able to solve global challenges is not new in the history of the United Nations (UN) and UNESCO (see Petersen 2021). In 2012, the Secretary General of the United Nations (UN) promoted the "Global Education First Initiative" (GEFI 2012), at the heart of which was the idea that education should be the most important driver of the transformations necessary to solve emerging global challenges. According to GEFI (2012, p. 20), 
"education must fully assume its central role in helping people to forge more just, peaceful, tolerant and inclusive societies", and it was highlighted that it is "not enough for education to produce individuals who can read, write and count". In 2015, the importance of education was similarly underlined in another publication, "Global citizenship education: Topics and Learning Objectives" (UNESCO 2015). A statement from 2018 furthermore highlighted that:

Global Citizenship Education (GCED) aims to empower learners of all ages to assume active roles, both locally and globally, in building more peaceful, tolerant, inclusive and secure societies. (UNESCO 2018; bold: mine)

UN and UNESCO are, however, not the only worldwide organisations focusing on education as means of solving vital issues.

Another vital player at the international scene is the Organization for Economic Cooperation and Development (OECD), which for years has played an immense role in the formation of nation-state education policy in many areas of the world (Pettersson, Popkewiz \& Lindblad 2017). Large-scale assessments, such as the Programme for International Student Assessment - PISA (OECD 2021b) and the OECD Country "Reviews on Evaluation and Assessment Frameworks for Improving School Outcomes", are being carried out through a vast and increasing number of countries (OECD 2021c) and have largely influenced nation-state policy.

While emphasising education, OECD outlines their intentions regarding supporting nationstates in a slightly different way than UNESCO:

The OECD's work on education helps individuals and nations to identify and develop the knowledge and skills that drive better jobs and better lives, generate prosperity and promote social inclusion. (OECD 2021a; bold: mine)

However, not only international organisations have focused on education as playing a critical role. In addition, educational philosophers and thinkers have emphasised the role of education in transforming society. John Dewey's (1916) credo Democracy and Education and Paulo Freire's (1970) Pedagogy of the Oppressed are well-known examples and, current educators discuss and reflect upon education as a means of developing individuals in social contexts and developing value- and virtue-based education (Biesta, 2010, 2015).

Education hence is of great importance, and furthermore, in the history of combating illiteracy, education has been a core element, and the access and possibility for acquiring basic education are considered a human right, an example of which is "The Resolution on Education for All and Combating Illiteracy" (The Second World Congress of Education International 1998).

Education, furthermore, has also come to the attention of many politicians, and the past decades have witnessed a transformation of education policy in many countries. While earlier political discourses have emphasised that education is seen as supporting welfare states and developing individual democratic citizens (Nordenbo 2008), recent decades' mainstream educational research and education policy has been understood in discourses of neoliberal education policy (Apple 2011; Ball 2006; Carr 2011; Nordenbo 2008). In the past two decades, such a tendency is also seen in the Scandinavian countries (Dovemark et al. 2018; Imsen, Blossing \& Moos 2017; Petersen et al. 2021).

However, in the wake of an increasing critique of neoliberal education policy fostering negative implications (Ball 2005; 2015; Biesta 2010; 2015, Dovemark et al. 2018; Imsen, Blossing \& Moos 2017), an emphasis on value- and virtue-based education as opposed to skills- and competency-based education has come to the fore in recent discussions (Biesta 2010; Banks 2018; Peterson \& Arthur 2020; Salloum 2017). 
In this article, I will set out to discuss the differences in skills- and competency-based approaches to education as opposed to value- and virtue-based, and drawing on which I will discuss the approaches to education of OECD compared to UNESCO. Based on this, I will briefly discuss how a (global citizenship) education for (unknown) futures might look like. The article is hence a reflection paper.

\section{Skills- and competency-based or value- and virtue-based education?}

The Scottish researcher David Carr (2011) emphasises how past decades of education research, and in particularly Anglo-American education research and policy, have focused on education and teacher training as "a matter of acquisition of repertoires of (...) skills or competences", t.i. on a skills- and competency-based approach to education. Carr writes:

Over a long modern period, Western educational research has been mainly focused on the empirical discovery of causally effective methods of learning, instruction or behaviour management, and British, American and other colleges of education have promoted a conception of teacher training as a matter of the acquisition of repertoires of such skills or 'competences' ( $p$. 174).

A short introduction to the history and development of the skills- and competency-based approach to education therefore seems appropriate.

\section{Skills-and competency-based approaches to education and the critique}

The American educator and educational researcher Spady (1977, p. 10) was one of the first to define competency-based education as "a data-based" and "performance-oriented" way of teaching, that facilitates, measures, records and certifies demonstration of knowledge, often described as outcome-based education. Spada defined competency-based education (CBE) as:

adaptive, performance-oriented set of integrated processes that facilitate, measure, record and certify within the context of flexible time parameters the demonstration of known, explicity stated, and agreed upon learning outcomes that reflect successful functioning in life roles (Spady 1977, p.10).

In the American context, competency-based education has been evolving since, which among others Kelchin (2015) describes in a report on "The Landscape of Competency-based Education" in the United States, while Nodine (2016) in an in 2016 established Journal of Competency-based Education, evidences how higher education in the US has embraced competencybased education. Walton (2017, n.p.) summarises that competencies in competency-based education "include explicit, measurable, transferable learning objectives", that "assessment is meaningful and a positive learning experience for students", and that "students develop and apply a broad set of skills and dispositions". According to Carr (2011) however, an approach to education that encourages the acquisition of specific skills and competencies, and brings to the fore an idea that becoming a good and effective teacher is similar to acquiring such skills, be it pedagogical or managerial skills, implies an understanding that anyone will be able to obtain these skills. A skills- and competency-based approach to education, Carr writes:

encourages the view that all there is to becoming a good, effective or successful teacher is the acquisition of a set of 'off-the-peg' educationally all-purpose skills in much the same way that acquisition of auto-repair skills might equip someone (anyone) to be a good car mechanic. Such

91

Karen Bjerg Petersen

Futures of Education, Culture \& Nature - Learning to Become 
a view also clearly reinforces the 'liberal' distinction between the professional and the personal: on this view, since all it takes to be a good teacher is to have mastered relevant pedagogical or managerial skills, any rogue or rapscallion might become a good teacher (p. 174).

Carr emphasised that although education researchers have tried to "discover 'evidencebased' principles and procedures for effective pedagogy or school management", such principles can be widely discussed and, "it is far from clear that such principles are available in the real world of educational practice" (p.174).

Carr is not alone in the critique of recent decades' mainstream educational research and education approach. Many researchers have pointed to the fact that neoliberal education policy, which often has been associated with the introduction of skills- and competency-based education (Ball 2006) has changed the focus in education (Apple 2006; 2011; Ball 2005, 2015; Biesta 2010; 2015). As pointed out by Petersen \& Mower initially, the "concept of neoliberalism has been associated to mostly economic policy focusing on privatisation, free trade, and marketisation in order to increase the role of the private sector in economy and society" (2019, p. 54).

In the 1980s and 1990s, neoliberalism was introduced in British education policy (Ball 2006). The British educational researcher Stephen Ball (2006) being one of the first to identify the changes towards a neoliberal education policy emphasised five main elements in the transformation of education policy in terms of neoliberal thought patterns:

1) improving national economics by tightening a connection between schooling, employment, productivity and trade; 2) enhancing student outcomes in employment related skills and competencies; 3) attaining more direct control over curriculum content and assessment; 4) reducing the costs of government to education; 5) increasing (...) pressure of market choice. (Ball 2006, p. 70; italics: mine)

In 2001, with the so-called No-Child-Left Alone Act (Klein 2018), standards-based education reforms, testing and measurement were introduced in the United States (Berliner 2009), "that allowed the government to determine the priority of subjects to be taught, the way they might be taught, and reforms available to schools that do not perform" (Petersen \& Mower 2019, p. 54).

In the wake of an increasing influence of neoliberal education policy, however, at the same time, there has been growing criticism among many educators towards the new discourse. Researchers have pointed to negative implications in terms of tendencies to teaching-to-thetest activities, narrowing of curriculum, and on education as aiming to heighten nation-state competitiveness on the global market rather than focusing on the development of the individual as a democratic and unique citizen (Apple 2006; 2011; Ball 2005; 2015; Biesta 2010, 2015).

Apple (2011) outlined that "new managerial proposals" have installed "rigorous and reductive forms of accountability in schooling at all levels" (p. 21). Ball (2015) pointed to the fact that neoliberal education policy has led to education, teaching, and teachers to being "governed by numbers" (p. 299). According to Ball, "numbers define our worth, measure our effectiveness and, in a myriad of other ways, work to inform or construct what we are today. We are subject to numbers and numbered subjects" (p. 299). The measurement, monitoring, and numbers have taken over our personal and work lives resulting in focusing on students' test scores and other performances. In 2015, Ball wrote:

Measurement and monitoring as techniques for reflection and representation play a particular role within the contemporary relationship between truth and power and the self that we call neoliberalism. As neoliberal subjects, we are constantly incited to invest in ourselves, work on ourselves and improve ourselves - drive up our numbers, our performance, our outputs - both 
in our personal lives and our work lives. (p. 299)

David Carr (2011), and with him a range of other educational authors and philosophers have started discussing the loss of value and virtue in education as an implication of neoliberal education policy and the focus on skills- and competency-based education (Biesta 2010; Banks 2018; Boon 2011; Carr 2011; Cambell 2006; Peterson \& Arthur 2020; Salloum 2017).

In light of a discussion of the (unknown) futures of education and in consideration of the approaches of UNESCO and OECD respectively, it is relevant to take a closer look those educators promoting the idea of a value- or virtue-based education.

\section{Value-and virtue-based approaches to education}

The Australian teacher educator, Boon (2011), emphasises the importance of value- and virtue-based approaches in education by outlining that teaching has 'a moral nature' that can not be separated from the focus on 'skills', which on the other hand means that explicit attention to the moral formation of teachers in for example teacher education is of high importance:

The moral nature of teaching cannot be conflated with the knowledge and skills important for teaching; neither can it be neatly separated from them. As we have known throughout the ages yet also frequently ignore, the moral is always in play in classrooms in teachers' actions, whether intentionally or not, and the complexity of the classroom environment--its immediacy and everchanging activities - makes demands on teachers that reveal their orientation to their work in a myriad of daily acts. Because of that seamless connection, explicit attention to the moral formation of (...) teachers is crucial (p.79).

Boon (2011) defines value-based education " known internationally by various names, including moral education, character education and ethics education" as "a globally endorsed move that charges teachers and schools with the role of inculcating values to their students, abandoning prior beliefs that these are only in the domain of families and religious institutions" (p.80).

David Carr (2011) in his critique of skills-based education approaches, emphasises that what teachers need "in order to be effective":

are not all-purpose off-the-peg rules, but capacities for contextually sensitive reflection, deliberation and judgement in the actual various and varying professional and pedagogical contexts in which they daily find themselves (p. 174).

Carr continues that "it has been less widely noticed that such ethics of contextually sensitive judgement is more or less tantamount to an 'ethics of virtue'" (p.174). Carr thus emphasises that what teachers:

may need for effective classroom authority and discipline are not reducible to management techniques, [but] ... moral virtues of courage, honesty and justice (p.174).

Salloum (2017 p. 355) echoes Carr's arguments and emphasises that, "a virtue-based education binds knowledge with moral concepts" and, she furthermore argues that the:

cultivation of 'morally good' character is not merely helpful in good teaching, but is constitutive of it, especially cultivating virtues such as honesty, justice, patience, and courage (p. 356). 
The virtues "honesty, justice, patience, and courage" hence are seen as essential in a virtuebased approach to education that does not neglect an emphasis on skills but highlights "nonpositional goods" (Nordenbo 2008) as crucial for education.

Banks (2018) investigating virtue-based approaches to research integrity, emphasises that virtue ethics as a philosophical approach linked to Aristotle "focusses on the excellent qualities of character or moral dispositions (virtues) of moral agents. Examples of virtues might include trustworthiness, courage or compassion" (p. 23). In this article, in continuation of Banks' definition, the term "virtue" refers "to a moral disposition to feel, think and act in such a way as to promote human and ecological flourishing, entailing both a motivation to act well and, typically, the achievement of good ends" (p.25).

While a skills- and competency-based approach to education emphasises that the critical focus in education has to be on which skills and competencies are relevant for future educations, a virtue-and value-based approach points to the fact that the acquisition of specific skills and competencies on their own are not enough for future education and teachers. On the contrary, a virtue- and value-based approach emphasise the on-the-spot sensitivity of teachers and learning, in which honesty, justice, patience, and courage play a crucial role.

\section{Concepts of education and training - two traditions: OECD versus UNESCO}

At this point in the article, it is relevant to return to the two approaches towards education mentioned in the introduction to this article - the approach of OECD and UNESCO.

\section{Concepts of education: OECD}

As mentioned in the introduction, the focus of OECD is to help individuals and nation-states "to identify and develop the knowledge and skills that drive better jobs and better lives" (OECD 2021a). Although it is difficult to judge an organisation solely based on its statements on its website, one might argue that the underlying understanding of education of OECD, emphasising that the acquisition of specific "skills" may "drive better jobs and better lives" and can "generate prosperity" for nation-states echoes a skills- and competency-based approach to education that argues that the acquisition of certain "off-the-peg" (Carr 2011, p.174) skills can contribute to the development of a country.

In addition, the focus on standards, skills and testing as core elements to drive "better lives", i.e. the PISA tests, carried out by OECD in various nation-states, can similarly be taken as evidence of a trend towards a skills- and competency-based approach to education. In many ways, this approach mirrors a neoliberal education policy, described above in the second of the five main elements, mentioned by Ball (2006). According to Ball $(2006$, p. 70) the aim of a neoliberal education policy is, among others, to improve nation-states economies by enhancing student outcomes in employment-related skills and competencies, a promise that is at the forefront of OECD's argument for a skills- and competency-based education. A way to achieve this in neoliberal education policy, according to Ball, is to attain "more direct control over curriculum content and assessment" (p.70). As we will see below, the implementation of the PISA tests have helped give governments in many countries, including Denmark, control over curriculum content and assessment (Aftale 2013).

As mentioned among others by Pettersson, Popkewiz and Lindblad (2017), large-scale worldwide assessments like the PISA tests have actually had a significant impact on many nation-states' education policy and actions towards heightening the nation-state's ranking on

94

Global Citizenship Education for (Unknown) Futures of Edcuation

Futures of Education, Culture \& Nature - Learning to Become 
the PISA list. This has also been the case in Scandinavian countries (Dovemark et al, 2018; Imsen, Blossing \& Moos 2017). In fact, a publication from OECD (2012) emphasises that the policy impact of Pisa has been tremendous, not least in the Scandinavian countries and Denmark.

OECD (2012) in an Education Working Paper entitled The Policy Impact of Pisa: An Exploration of the Normative Effects of International Benchmarking in School System Performance, emphasises how the "PISA shock" had opened policy windows in many countries:

Confronted with lower-than-expected results in student performance, PISA triggered a sustained public debate about education policy and reform that came to be known as 'PISA shock'. The PISA-inspired debate over public education has resulted in a range of significant reform measures, including generating national standards (OECD 2012, p.5).

That Denmark and other countries are no exception is underlined in the OECD paper, in which it is explicitly mentioned that the "PISA results are used as an external trigger for large-scale public debate on education and relatively rapid policy dialogue and policy change (e.g. Germany and Denmark)" (p.15).

In Denmark thus, a range of education reforms, including a teacher education reform (BEK $\mathrm{nr} 231$ 2013), and a reform of primary and lower secondary public school (Folkeskole) focusing on national standards, competencies and introducing nationwide testing in the school curriculum were implemented in the 2010s (LBK nr. 665 2014). Wording and subject description in the act were changed from "goals" [mål] to "competency goals" [kompetencemål] (LBK nr. 406 2014, 7). Interestingly, in an Agreement Paper from 2013 between the then government and political parties, agreeing on implementing a new reform of the Danish Folkeskole, the OECD results are specifically mentioned:

But the Danish primary and lower secondary school also faces major challenges. The efficiency level - especially in reading and mathematics - is not high enough. Danish school students are around the OECD average in Danish, Mathematics and Science when they leave primary school (Aftale 2013, p. 1; own translation).

Hence, the PISA tests and OECD's approach to education have had a great impact on nationstate education policy, Denmark being no exception, on the implementation of education reforms and on an attitude and understanding of education, that can be said to be based primarily on a skills- and competency-based approach.

\section{Concepts of education: UNESCO}

In contrast to OECD, there are quite a few differences in the UNESCO approach to education. Whereas OECD intends to help nation-states and people to develop "skills that drive better jobs and better lives" (OECD 2021a), the focus of UNESCO is different.

As mentioned in the introduction, the Global Education First Initiative emphasise that the central role of education consists "in helping people to forge more just, peaceful, tolerant and inclusive societies" (GEFI 2012, p.20). In the document from 2012, it is explicitly mentioned that the acquisition of skills and competencies is not seen to be sufficient. The introductory sentence in the GEFI document from 2012 that it is "not enough for education to produce individuals who can read, write and count" evidences a different approach to the aim of education. The UNESCO quote from 2018 about "Global Citizenship Education" as aiming "to empower learners" to "building more peaceful, tolerant, inclusive and secure societies" is a repetition of the 2012 statement. As we have seen in the introduction, such understanding and the role of education seems to be pervasive in the UNESCO and UN documents up through 
the 2010s. Many of the statements and documents from UNESCO regarding education in general as well as the concepts of global citizenship education emphasises concepts and moral virtues such as justice, tolerance, inclusion, peace.

In many ways hence, the UN and UNESCO approach to education echoes a virtue-based approach to education as described above by Carr (2011), Boon (2011), Salloum (2017), Banks (2018) and Peterson \& Arthur (2020). Students and teachers in the approach of UNESCO and UN in continuation of Carr's statements (2011) must have "professional capacities" that "are not reducible to management techniques", but rather "require moral virtues of courage, honesty and justice" (p.176). Also, Salloum's statement (2017 p. 355) that, "a virtue-based education binds knowledge with moral concepts" and, that "cultivating virtues such as honesty, justice, patience, and courage" (p. 356) are crucial for education mirror the UN and UNESCO approach in the highlighting of moral virtues as being crucial in global citizenship education. Banks' (2018) definition of the notion of 'virtue' as "a moral disposition to feel, think and act in such a way as to promote human and ecological flourishing" (p.25) is in alignment with the underlying requirements for education purposes and teacher qualifications forwarded by the UN and UNESCO with respect to teacher qualifications and the purpose of education. The strong belief in education promoted in the virtue-based approach of UNESCO and the UN seems to imply that education involves both a motivation to act well and to achieve good goals, as mentioned by Banks in his definition of virtue-based approaches (2018, p. 25).

While the OECD approach to education can be said to be tending to a skills- and competency-based approach, the UNESCO and UN approach is more grounded on a virtue- and value-based understanding of education. But must education, and especially the future of education be either skills- and competency-based or value- and virtue-based?

\section{Reflections of (global citizenship) education for unknown futures}

The Australian researcher, Raewyn Connell (2009) in his article Good teachers on dangerous ground: towards a new view of teacher quality and professionalism, in many ways discuss the contradictions in education research and approaches to education in the past decades as either skills-based or virtue-based. According to Conell, it is essential to take into account the actual, practical day-by-day work with education while at the same time being aware of the fact that education is "a process of forming a culture" (p.221). Conell writes:

Good teaching must be sustainable (...) Classroom life involves a flow of emotions, both on the part of the teachers and the pupils, ranging from simple likes and dislikes to enthusiasm, anxiety, boredom, joy, fear and hope. Any teacher has to manage this flow, and make it productive for the pupils' learning and survivable for herself or himself (..). Education is a process of forming a culture". (p.221)

In this article, Denmark has been used as an example of a country in which the OECD tests and the PISA-shock have been prevalent in the 2000s resulting in changes in education reforms for both teacher education and primary and lower secondary school in the 2010s. Since 2000, the PISA tests have been performed at 3-year intervals and Denmark participated since 2000. A decade later, however, new discussions have arisen. In 2018, the overall PISA results for Denmark since the first participation in 2000 were assessed. According to an OECD country note on Denmark in 2018, the performance in Denmark since 2000, however, remains more or less stable. The country report notes that:

Mean performance in reading remained stable, around a flat trend line, throughout Denmark's

96

Global Citizenship Education for (Unknown) Futures of Edcuation

Futures of Education, Culture \& Nature - Learning to Become 
participation in PISA. In mathematics and science too, no overall direction of the trend could be detected; however, in mathematics, a declining trend up to 2012 was followed by a (partial) recovery over the 2012-18 period, while in science, performance in 2018 was about nine score points lower, on average, than in 2015 (OECD 2018, p. 3).

Despite the education reforms in the 2010s focusing on primary and lower secondary school in Denmark thus, the PISA results of the country in many ways did not differ dramatically in the past decades. On the contrary, a lower performance in science in 2018 despite the reforms to heighten the performance was noted.

The PISA tests have been discussed by many researchers, including Danish Statistical researchers, emphasising a "misfit of the PISA scaling model" and evidencing that closer analysis of the PISA data "do not support the claims that the country rankings reported by PISA are robust" (Kreiner \& Christensen 2014, p. 210). In an interview in 2014, one of the authors, Kreiner expressed his concern outlining, "implementing reforms based on PISA is very problematic" (Ejlertsen 2014, n.p.). In the interview, Kreiner continues:

In Denmark, there has been no positive effect of PISA's own test figures for now 13 years. This is because what PISA says does not have much to do with reality. The changes that have been tried to be implemented in the Danish school have taken place on an unqualified basis, which has led to distrust of the entire primary and lower secondary school. (Ejlertsen 2014, n.p.)

Moreover, in 2019, the chairperson of the Danish Teachers' Association DLF concluded that the reforms carried out in Denmark because of the Pisa-chok had not succeeded. He said, "It cannot be said that the 2000s policy that national tests and increased focus on Pisa results should raise students' academic level has succeeded" (Mikkelsen 2019).

As a result, prophecies about a new development of the school in the 2020s have been put forward, "The 2020s are coming: the primary and lower secondary school will have fewer tests and more quality.... a broader view of the school's purpose is on the way" (Oxenbøll 2019).

The discussion of education as being either skills- and competency-based or value-and virtue-based have in this article been discussed as if they inevitably exclude each other; however, such dichotomies might be less helpful for education in the future. Rather than focusing on either of these approaches, a fusion of them seems necessary.

Carr (2011) in his argument for including virtue-based approaches in education focused on the importance of knowledge to be cultivated and achieved in education and to be skilfully introduced by teachers. He forwarded the idea that not only requirements for "moral virtues of courage, honesty and justice" are important. Also "intellectual virtues" in terms of "academic and procedural knowledge" are crucial for education (p. 176).

(Global citizenship) education as described in the UN and UNESCO documents is in many ways an expression of an idealistic understanding of what education can do and achieve grounded on a virtue-based approach to education as being able to "building more peaceful, tolerant, inclusive and secure societies" UNESCO, 2018). The position calls upon a strong belief in education to being able to solve the urgent global issues and challenges. As mentioned in the introduction, the participants in UNESCO 2020 the world survey regarding global challenges, however, also mentioned multilateralism as a means to solve global issues such as climate change and loss of biodiversity (UNESCO Clearing House, 2020). Although multilateralism does not play an essential role in the UN and UNESCO documents about global citizenship education, there is no doubt that multilateralism in the form of worldwide cooperation on climate change and loss of diversity is of immense importance.

Future education in continuation of Carr's (2011) emphasis on a combination of a virtue-, and knowledge-based education might however be a way to develop education for the future: 
The good teachers of moral, epistemic and craft virtue, then, are those to whom positive moral association, knowledge and its skilful presentation are no less significant for individual personal development than they are for the development of others. (Carr 2011, p. 176).

With Carr's words it seems to be "a tall order for professional development", but probably Carr is right concluding "it would be wrong to settle for less" (p.176).

\section{Literature}

Aftale (2013). Aftale mellem regeringen (Socialdemokraterne, Radikale Venstre og Socialistisk Folkeparti), Venstre og Dansk Folkeparti om et fagligt løft af folkeskolen. 7. Juni 2013. Retrieved from file:///C:/Users/au85110/Downloads/141010-Endelig-aftaletekst-7-62013.pdf

Apple, M. W. (2006). Educating the "right" way: Markets, standards, God, and inequality. New York: Routledge.

Apple, M. W. (2011). Education and power. New York: Routledge.

Ball, S. J. (2006). Education policy and social class: The selected works of Stephen J. Ball. London: Routledge.

Ball, S. J. (2015). Education, governance and the tyranny of numbers. Journal of Education Policy, 30(3), 299-301. doi: 10.1080/02680939.2015.1013271

Banks, S. (2018), "Cultivating Researcher Integrity: Virtue-Based Approaches to Research Ethics", Emmerich, N. (Ed.) Virtue Ethics in the Conduct and Governance of Social Science Research (Advances in Research Ethics and Integrity, Vol. 3), Emerald Publishing Limited, Bingley, pp. 21-44. https://doi.org/10.1108/\$2398-601820180000003002

BEK nr 231 (2013). BEK nr. 231 af 08/03/2013. Bekendtgørelse om uddannelsen til professionsbachelor som lærer i folkeskolen. Retrieved from https://www.retsinformation.dk/eli/lta/2013/231

Berliner, D. C. (2009). The incompatibility of high-stakes testing and the development of skills for the 21st century. In R. Marzano (Ed.), On excellence in teaching. Bloomington: Solution Tree Press.

Biesta, G. J. J. (2010). Why 'what works' still won't work: From evidence-based education to value-based education. Studies in Philosophy and Education, 29, 491-503.

Biesta, G. (2015). What is education for? On good education, teacher judgement, and educational professionalism. European Journal of Education 50(1), 75-87. https://doi.org/10.1111/ejed.12109

Boon, H. J. (2011). Raising the bar : ethics education for quality teachers. Australian Journal of Teacher Education, 36(7), 76-93. https://files.eric.ed.gov/fulltext/EJ937001.pdf

Carr, D. (2007). Character in teaching. British Journal of Educational Studies, 55(4), 369-389. doi:10.1111/j.1467-8527.2007.00386.x

Carr, D. (2011). Values, virtues and professional development in education and teaching. International Journal of Educational Research, $50 \quad$ (3), 171-176 https://doi.org/10.1016/i.ijer.2011.07.004.

Connell, R. (2009). Good teachers on dangerous ground: towards a new view of teacher quality and professionalism, Critical Studies in Education, 50 (3), 213-229, DOI: 10.1080/17508480902998421 
Dewey, J. (1916). Democracy and Education: An Introduction to the Philosophy of Education. Macmillan.

Dovemark, M., S. Kosunen, J. Kauko, B. Magnasdottir, P. Hansen \& P. Rasmussen (2018). Deregulation, privatisation and marketisation of Nordic comprehensive education: social changes reflected in schooling, Education Inquiry, 9 (1), 122-141, DOI: 10.1080/20004508.2018.1429768.

Ejlertsen, M. (2014, January 17). PISA-test har skadet uddannelsessektoren. Magisterbladet.

1, Retrieved from https://www.akademikerbladet.dk/magasinet/2014/magisterbladet-nr1-2014/pisa-test-har-skadet-uddannelses-sektoren

Freire, P. (1970). Pedagogy of the Oppressed. Continuum.

GEFI (2012). Global Education First Initiative. The United Nations Secretary General's Initiative to ensure quality, relevant and transformative education for everyone. https://issuu.com/globaleducationfirst/docs/gefi brochure eng.

Imsen, G., Blossing, U. \& Moos, L. (2017). Reshaping the Nordic education model in an era of efficiency. Changes in the comprehensive school project in Denmark, Norway, and Sweden since the millennium. Scandinavian Journal of Educational Research, 61(5), 568-583, DOI: 10.1080/00313831.2016.1172502.

Kelchen, R. (2015). The Landscape of Competency-Based Education. Enrollments, Demography and Affordability. AEI Series on Competency-Based Higher Education. New York: American Enterprise Institute for Public Policy Research.

Klein, A. (2018, May 1). No Child Left Behind: An overview. Education Week. Retrieved from https://www.edweek.org/ew/section/multimedia/no-child-left-behind-overview-definition-summary.html

Kreiner, S. \& Christensen, K. B. (2014). Analyses of model fit and robustness. A new look at the PISA scaling model underlying ranking of countries according to reading literacy. Psychometrika, 79 (2), 210-231. DOI: 10.1007/S11336-013-9347-Z, retrieved from https://link.springer.com/content/pdf/10.1007/s11336-013-9347-z.pdf

LBK nr 406 (2014). LOV nr 406 af 28/04/2014. Lov om ændring af lov om folkeskolen og forskellige andre love. Retrieved from https://www.retsinformation.dk/eli/lta/2014/406

LBK nr 665 (2014). Bekendtgørelse af lov om Folkeskolen af 20/06/2014/ Statutary Order on Primary and Lower Secondary School in Denmark. Retrieved from https://www.retsinformation.dk/eli/lta/2014/665

Mikkelsen, M. (2019, December 4). Danske elever er nummer 18 i læsning - og Pisa er ikke Gud. Kristeligt Dagblad. Retrieved from https://www.kristeligt-dagblad.dk/danmark/danske-elever-er-nummer-18-i-laesning-og-pisa-er-ikke-gud

Nodine, T.R. (2016). How did we get here? A brief history of competency-based higher education in the United States. The Journal of Competency-Based Education, 1(1), 5-11. https://doi.org/10.1002/cbe2.1004

Nordenbo, S. E. (2008). Fra progressiv til liberal pædagogik. In F. Collin \& Faye, J. (Eds.), Ideer vi lever på. Humanistisk viden i videnssamfundet. København: Akademisk Forlag.

OECD (2012). The Policy Impact of Pisa: An Exploration of the Normative Effects of International Benchmarking in School System Performance. OECD Education Working Paper, 7. Retrieved from https://www.oecd.org/officialdocuments/publicdisplaydocumentpdf/?cote=EDU/WKP(2012)8\&docLanguage $=$ En 
OECD (2018). Denmark - Country Note - PISA 2018 Results. Retrieved from https://backend.folkeskolen.dk/ /5/4/pisa2018cndnk.pdf

OECD (2021a). Education. Retrieved from https://www.oecd.org/education/

OECD (2021b). PISA. https://www.oecd.org/pisa/

OECD (2021c). OECD Review on Evaluation and Assessment Frameworks for Improving School Outcomes - Country Reviews. Retrieved from https://www.oecd.org/education/school/oecdreviewonevaluationandassessmentframeworksforimprovingschooloutcomescountryreviews.htm

Oxenbøll, E. (2019, December 12). 2020'erne kommer: Folkeskolen får færre tests og mere kvalitet. Kommunen.dk. Retrieved from https://www.kommunen.dk/artikel/2020-ernekommer-noget-om-folkeskolen

Petersen, K. B. (2021). Global Citizenship Education, Internationalisation and Global Concerns. Reflections from Denmark. In Petersen, K. B., Von Brömssen, K., Jacobsen, G. H., Garsdal, J., Paulsen, M. \& Kofoed, O. (Eds.). Rethinking Education In Light Of Global Challenges: Scandinavian Perspectives on Culture, Society, and the Anthropocene. London: Routledge.

Petersen, K.B. \& Mower, D. (2019). Teacher Education in a Post Nation State Era. A Possible Ecological Approach: A Discussion and Reflection. Journal of the International Society for Teacher Education, 23(2), 53-67.

Petersen, K. B., Von Brömssen, K., Jacobsen, G. H., Garsdal, J., Paulsen, M. \& Kofoed, O. (Eds.). Rethinking Education in Light of Global Challenges: Scandinavian Perspectives on Culture, Society, and the Anthropocene. London: Routledge.

Peterson, A. \& J. Arthur (2020). Ethichs and the Good Teacher. Character in the Professional Domain. London: Routledge.

Pettersson, D., Popkewiz, T. \& Lindblad, S. (2017). In the grey-zone: large-scale assessmentbased activities betwixt and between policy, research and practice. Nordic journal of Educational Policy, 3: 1 (29-41).

Salloum, S. (2017). The place of practical wisdom in science education: what can be learned from Aristotelian ethics and a virtue-based theory of knowledge. Cultural Studies of Science Education 12, 355-367 https://doi.org/10.1007/s11422-015-9710-8 https://link.springer.com/article/10.1007/s11422-015-9710-8

Spady, W. G. (1977). Competency Based Education: A Bandwagon in Search of a Definition. Educational Researcher, 6 (1), 9-14

Second World Congress of Education International (1998) Resolution on Education for All and Combating Illiteracy, The Second World Congress of Education International, meeting in Washington D.C., USA from 25 to 29 July 1998. Retrieved from https://www.eiie.org/en/item/21465:resolution-on-education-for-all-and-combating-illiteracy

UNESCO (2015). Global Citizenship Education: Topics and Learning Objectives. United Nations Educational, Scientific and Cultural Organization. Retrieved from http://unesdoc.unesco.org/images/0023/002329/232993e.pdf d. 19.9.2018

UNESCO (2018). Global Citizenship Education. Retrieved from
https://en.unesco.org/themes/gced 
UNESCO Clearing House on Global Citizenship Education (2020). "World in 2030" Public Survey: climate change and biodiversity loss biggest concern by far, multilateralism and education most important solutions. Retrieved from News | Global Citizenship Education (GCED) Clearinghouse I UNESCO \& APCEIU (gcedclearinghouse.org)

Walton, J. (2017, December 12). Competency-Based Education: Definitions and Difference Makers. Retrieved from https://www.gettingsmart.com/2017/12/12/competency-basededucation-definitions-and-difference-makers/ 